\title{
Imperatiiv ja konditsionaal ungari ja võrdlevalt eesti kõrvallauses
}

\author{
TIINA RÜÜTMAA
}

Tallinna Ülikool

Ülevaade. Artikkel kõrvutab imperatiivi ning konditsionaali funktsioone ungari ja eesti kõrvallauses eesmärgiga kaardistada vaadeldavate kõneviiside omavahelisi seoseid.

Esmalt antakse ülevaade imperatiivist (jussiivist) ja konditsionaalist kaasaegses ungari ja eesti grammatikakäsitluses, seejärel kõrvutatakse ungarikeelsetest tekstidest leitud imperatiivi- ja konditsionaalivormis predikaadiga kõrvallauseid nende eesti vastetega.

Ungari imperatiiv on komplitseeritud kõneviis, mis lisaks käsu väljendamisele täidab ka konjunktiivi ülesandeid; ungari konditsionaali funktsioon aga on peamiselt tingimuslikkuse väljendamine. Sarnaselt ungari imperatiivile on konjunktiivi ülesandeid omistatud ka eesti konditsionaalile; eesti imperatiivi (jussiivi) põhifunktsioon aga on väljendada käsku.

Ungari imperatiivi väljendamiseks on eesti keeles mitmekesised võimalused, kusjuures imperatiiv (jussiiv) on nende seas küllalt haruldane. See kinnitab, et ungari kõrvallause imperatiivivorm on enamasti konjunktiivi funktsioonis, käsku väljendab see harva. Ungari konditsionaalile aga vastab eesti keeles eelduspäraselt enamasti konditsionaal.

Võtmesõnad: kontrastiivlingvistika; morfosüntaks; põimlause; otstarbelause; jussiiv; konjunktiiv; subjunktiiv; eesti keel; ungari keel 


\section{Sissejuhatus}

Artiklis kõrvutatakse kõneviisisüsteemi ungari ja eesti kõrvallauses, pöörates põhitähelepanu imperatiivile ja konditsionaalile kui kõneviisidele, mille funktsioonid on vaadeldavates keeltes tavapärasest erinevad (ülevaatlikult ungari ja eesti kõneviisisüsteemist kõrvallauses vt Rüütmaa 2007).

Ungari grammatikad nimetavad traditsiooniliselt kolme kõneviisi: indikatiivi (kijelentő mód), konditsionaali (feltételes mód) ja imperatiivi (felszólító mód). Viimasel ajal on siiski palju arutletud ka eraldi morfoloogilise tunnuseta neljanda kõneviisi, konjunktiivi (kőtőmód) olemasolu üle (nt Prileszky 1974; Pataki 1984; Pomozi 1991; Molnár 1995; É. Kiss 1999; MLN 2001; Tóth 2005).

Eesti varasem grammatikatraditsioon eristas nelja kõneviisi: indikatiiv (kindel), konditsionaal (tingiv), imperatiiv (käskiv) ja kvotatiiv (kaudne kõneviis). Kaasaegsetes grammatikates lisandub nimetatutele vahendatud käsku väljendav jussiiv, nt EKG I (1995), EKG II (1993).

Esmalt antakse lühiülevaade imperatiivi (jussiivi) ja konditsionaali käsitlusest kaasaegsetes ungari ja eesti grammatikates ja uurimustes ning kõrvutatakse kõnealuste kõneviiside funktsioone kõrvallauses. Artikli teise osa ungarikeelsed näitelaused on pärit viidatud grammatikatest ja uurimustest. Näitelausete selgitamisel on kasutatud glosse lihtsuse huvides vaid juhul, kui ungari ja eesti vorm/konstruktsioon ei kattu. Kuna imperatiivil on vaid olevikuvormid, pole imperatiivivormi puhul aega märgitud. Eestikeelsed näitelaused tuginevad autori keeletajule. Ungarikeelsete grammatikaterminite tõlkimisel on toetutud László Keresztesi teosele "Praktiline ungari keele grammatika" (1997). Artikli kolmandas osas kõrvutatakse kõnealuste kõneviiside kasutust ungari ja eesti kõrvallauses ungarikeelsetest tekstidest pärinevate põimlausete ja nende eestikeelsete tõlkevastete põhjal eesmärgiga kaardistada vaadeldavate kõneviiside omavahelisi seoseid. 


\section{Imperatiiv ja konditsionaal ungari ja eesti kõrvallauses}

\subsection{Imperatiiv ungari kõrvallauses}

Ungari imperatiivil (felszólitó mód) on täielik paradigma (én ugor-j-am, te ugor-j[ál], ö ugor-j-on [ék], mi ugor-j-unk, ti ugor-j-atok, ők ugor-j-anak 'hüppama'). Lisaks tavapärasele käsu/soovi/palve väljendamisele hõlmavad selle funktsioonid kõrvallauses ka paljude indoeuroopa keelte konjunktiivi ehk subjunktiivi ülesandeid (nt Tompa 1972: 62; Prileszky 1974: 474; Pataki 1984: 208; Pomozi 1991: 4; Kugler 2000: 107-108; MLN 2001: 167; Aradi 2004: 1-4). Viimast defineeritakse tavaliselt kui kõneviisi, mis esineb peamiselt kõrvallauses ja mille kasutuse tingib pealause (enamasti selle predikaadi) semantika (nt Palmer 2001:3-5; Givón 2001: 312-313; Marques 2009: 179). Eelnevast tulenevalt esineb imperatiivi ungari kõrvallauses küllalt sageli.

Klassikalises ungari grammatikatraditsioonis pole imperatiivi erinevatele funktsioonidele eriti palju tähelepanu pööratud. Enamasti on vaid põgusalt mainitud vormilt imperatiivse, ent sisult mitte käsku väljendava predikaadi esinemist teatud liiki kõrvallausetes (nt MMNyR 1962). Tõsisemalt tõstatati imperatiivi sekundaarse funktsiooni küsimus peamiselt kontrastiivsetes uurimustes, enamasti keeleõppevajadustest lähtuvalt (nt Pataki 1984; Pomozi 1991; Hegedüs 1990). Tõdeti, et ungari imperatiiv võtab enda kanda ka konjunktiivi funktsioonid (nt Pataki 1984: 209-217; Pomozi 1991: 3-11; Pusztay 1998: 29), ent kaheldi siiski, kas seda tuleks käsitleda eraldi kõneviisina. Enamasti piirduti konjunktiivi käsitlemisel imperatiivi semantiliste lisafunktsioonide mainimisega (nt Tompa 1972: 62; Prileszky 1974: 474; Pomozi 1991: 4; Molnár 1994: 41-42; É. Kiss 1999: 141-142; Kugler 2000: 107-108; MLN 2001: 167). Nüüdseks on teema jõudnud ka uuematesse ülevaategrammatikatesse, kus imperatiivivormi kõnealust funktsiooni käsitletakse juba iseseisva keelelise kategooriana, ehkki kõneviiside hulgas seda veel eraldi esile ei tooda (nt É. Kiss 1999; MG 2000; MLN 2001). Uudse lähenemisega on Rita Hegedüsi grammatika "Magyar nyelvtan. Formák, funkciók, összefüggések” (2005). Selles on kötőmód 'konjunktiiv' hõivanud vormiõpe- 
tuse osas imperatiivi koha ning seda defineeritakse kui kõneviisi, mis väljendab igasugust kavatsetud, plaanitud, soovitud, veel teostumata tegevust, sh otsest ja kaudset käsku ning tulevikus kavatsetavale tegevusele viitavat kaudset väidet ja küsimust (Hegedüs 2005: 49-51, 259-266). Sarnasele järeldusele jõuab ka Casper de Groot, kes peab ungari imperatiivivormi pigem subjunktiiviks (konjunktiiviks), mille funktsioon on väljendada teatud käitumist eeldavat (behavourial) mittefaktuaalset (non-factual) suhtluseesmärki (Groot 2010).

Ungari kõrvallause imperatiivivorm võib seega (a) väljendada (vahendatud) käsku, s.o nn pärisimperatiiv (1a), kusjuures pealause predikaadi semantika tähtsust ei oma, st see ei pea sisaldama käsule viitavat semantilist tunnust, või (b) tuleneda pealause semantikast (1b), ehk olla konjunktiivi funktsioonis (Prileszky 1974: 474; Kugler 2000: 107; Hegedüs 2005: 49-52, 258-266).

(1a) A nővér azt mondta, hogy menjünk DEF-ART õde see:ACC.SG ütles et minema:IMP-INDET.1PL be a beteghez.

PREF DEF-ART haige:ALL.SG

'Õde ütles, et me läheks haige juurde.'

(1b) A

nővér megengedte, hogy

DEF-ART õde PREF:lubama:IND-DET.IMPERF.3SG et bemenjünk a beteghez. PREF:minema:IMP-INDET.1PL DEF-ART haige:ALL.SG 'Õde lubas meil haige juurde minna'

Kõrvallause predikaadi konjunktiivivormi tingivate leksikaalsete elementide põhilised tähendusrühmad on järgmised: (a) võimalus, lubamine (nt megenged 'lubama', lehetövé tesz 'võimaldama', alkalmat ad 'võimalust andma', megtilt 'keelama', lehetetlenné tesz 'võimatuks tegema', akadályoz 'takistama'); (b) vajadus (nt kell 'pidama', fontos 'tähtis', szükséges 'vajalik', kötelesség 'kohustus', nincs értelme 'pole mõtet', fölösleges 'ülearune'); (c) võime, valmisolek (nt igyekszik 'püüdma', kész 'valmis', képes 'võimeline', kedve van 'tahtmist olema', fél 'kartma', visszariad 'heituma', képtelen 
'võimetu') ja (d) eesmärk, tahe (nt akar 'tahtma', kíván 'soovima', óhajt 'soovima', szeretne 'tahaks'). Viimane tähendusrühm on üleminekuvorm, võimaldades valida imperatiivi (2a) ja konjunktiivi (2b) vahel (Prileszky 1974: 474; vt ka Kugler 2000: 107; Aradi 2004: 8-9).

(2a) Azt akarta, hogy látogassák meg. see:ACC.SG tahtis, et külastama:IMP-DET.1sG PREF 'Ta tahtis, et ma teda külastaks.'

(2b) Azt akarta, hogy meglátogassák. see:ACC.SG tahtis, et PREF:külastama:IMP-DET.1sG 'Ta tahtis, et ma teda külastaks.'

Eraldi tõstab Csilla Prileszky esile otstarbelause (3), kus kõneviisivalik tuleneb pea- ja kõrvallause loogikaseosest (Prileszky 1974: 474).

(3) Futásnak eredt, hogy elérje jooks:DAT.SG hakkas, et PREF:jõudma:IMP-DET.3sG

a villamost.

DEF-ART tramm:ACC.SG

'Hakkas jooksma, et trammi peale jõuda'.

Konjunktiivi kasutatakse ka kõrvallauses, mis väljendab millegi olemasolu või puudumist (4a), samuti tingib selle emfaatiline van 'olema' pealauses (4b) (Aradi 2004: 10-12).

(4a) Nincs, aki elmenjen.

pole, kes PREF:minema:IMP-INDET.3sG

'Pole, kes ära/sinna läheks.'

(4b) Vannak ők olyan okosak, hogy

olema:IND-INDET.PRES.PL3 nad nii targad, et

ne menjenek oda.

mitte minema: IMP-INDET.3sg sinna

'Nad on piisavalt targad, et sinna mitte minna.'

Lauseliikmelisusele põhinevast kõrvallause klassifikatsioonist lähtudes on imperatiivivormis kõige sagedamini alus-, sihitis-, juba mainitud otstarbelause ja teatud rektsioonimääruskõrvallause predikaat (Prileszky 
74: 473; Hegedüs 2005: 259-266), sidendist lähtuva jaotuse järgi aga hogy('et')-kõrvallause predikaat (Hegedüs 2005: 260).

Vormiliselt saab imperatiivi kaht põhifunktsiooni eristada ainult prefiksiliste verbide puhul: pärisimperatiivis kõrvallauses liigub verbiprefiks imperatiivile omaselt järelasendisse, konjuktiivi puhul aga jääb verbi ette (Prileszky 1974: 473-474; Pataki 1984: 209-217; Pomozi 1991: 3-11; Kugler 2000: 108). Lause tasandil ilmneb pärisimperatiivi ja konjuktiivi erinevus ka selles, et esimesel puhul võib sidesõna hogy 'et' ära jätta, ilma et lause ebagrammatiliseks muutuks $(5 \mathrm{a}, \mathrm{b})$, teisel puhul aga mitte (5c,d) (Pataki 84: 209-217; É. Kiss 1999: 141).
(5a) Azt
mondtam, hogy menj
el. see:ACC.SG ütlesin et minema:IMP-INDET.2SG PREF 'Ma ütlesin, et mine ära.'
(5b) Azt mondtam, menj
el. see:ACC.SG ütlesin minema: IMP-INDET.2SG PREF 'Ma ütlesin, mine ära.'
(5c) Nem engedem, hogy elmenj ei lubama:IND-DET.PRES.1SG et PREF:minema:IMP- INDET.2SG 'Ma ei luba sul ära minna'.
(5d) ${ }^{*} \mathrm{Nem}$ engedem, elmenj *ei lubama:IND-DET.PRES.1SG PREF:minema: IMP-INDET.2SG

Pärisimperatiivi ja konjuktiivi eristajana on esile toodud ka asjaolu, et paljudes soomeugri keeltes vastab viimasele infinitiivi- või partitsiibikonstruktsioon (vt ka tabel 2), samuti võib osa nimetatud kõrvallauseid ungari keeles infinitiivi- või partitsiibikonstruktsiooniga asendada (Pomozi 1991: 5; Pusztay 1998: 29; Aradi 2004: 5-8). 


\subsection{Imperatiiv eesti kõrvallauses}

Eesti imperatiivil on piiratud paradigma (sa maga, ta maga-gu, me maga-gem, te maga-ge, nad maga-gu), kusjuures ainsuse ja mitmuse 2. pööre ning mitmuse 1. pööre väljendavad otsest, 3. pööre aga kaudset käsku/soovi/palvet. Mitmuse 1. pöörde vorm väljendab pigem üleskutset ja kuulub kõrgstiili, nt Hakakem pihta! Neutraalstiilis asendab seda kindla kõneviisi mitmuse 1. pööre, nt Hakkame pihta! (EKK 2007: 91-96; vt ka Erelt \& Metslang 2004). Eesti keele teaduslik grammatika peab imperatiivi paradigmat veelgi piiratumaks: 3. pööre kui kaudset käsku väljendav vorm on sellest välja jäetud. Lähtutud on seisukohast, et tegevussituatsioonis mitteosalevale isikule ei ole võimalik otsest käsku anda, seega käsitletakse kõiki kõnelejalt 3. isikule suunatud käsku väljendavaid vorme jussiivina (EKG I 1995: 82, samuti "Eesti keele käsiraamatu” varasemad väljaanded, nt EKK 1997). Uusima arusaama järgi niisiis imperatiivi ja jussiivi kolmanda pöörde vormid kattuvad. Kaudset käsku eelistatakse siiski väljendada konditsionaali või $d a$-infinitiivitarindiga (6a, 6b) (Metslang 2004: 244; Metslang 2006: 113-114) Seega on eesti kõrvallauses imperatiiv suhteliselt haruldane, seda esineb peamiselt otsekõnesarnastes kõrvallausetes (Metslang 2004: 246; Metslang 2006: 113).

(6a) Kalle palus, et ma ostaks leiba.

(6b) Kalle palus mul leiba osta.

\subsection{Jussiiv eesti kõrvallauses}

Jussiivil on täielik paradigma $(\mathrm{ma} / \mathrm{sa} / \mathrm{ta} / \mathrm{me} / \mathrm{te} / \mathrm{nad}$ laulgu) ning see väljendab kohustust, mööndust või kaudset/vahendatud tegevusele õhutamist või käsku, mis on suunatud kõnelejalt kõnesituatsioonis mitteosalevale isikule või mis pärineb kõnesituatsioonis mitteosalevalt isikult (7a) (EKG I 1995: 83). Analoogilist funktsiooni täidavad ka deontilist modaalsust väljendavad modaalverbid (7b) ja las-tarind (7c) (EKG II 1993: 37). Jussiivi ja imperatiivi 3. pööre kattuvad, seega pole 
3. pöörde vormide puhul võimalik kõnealuste kõneviiside vahel vahet teha. Jussiiv on eesti keeles veel arenemisjärgus kõneviis ja seda esineb suhteliselt harva.

(7a) Kalle palus, et ostku Mart leiba.

(7b) Malle ütles, et Martinil tuleb oma tegude eest vastust kanda.

(7c) Isa arvas, et las Pille lõpetab enne väljaminekut koolitöö ära.

Ungari kõneviisisüsteemis jussiivi ei eristata, imperatiivivorm väljendab ka vahendatud käsku/soovi/palvet.

\subsection{Konditsionaal ungari kõrvallauses}

Ungari konditsionaal (feltételes mód) on alati modaalse tähendusega, selle funktsioonid kõrvallauses piirduvad põhiliselt tingimuslikkuse väljendamisega. Tingivas kõneviisis predikaat viitab võimalikule olukorrale, protsessile või tegevusele. Alati kasutatakse konditsionaali sidesõnaga mintha 'justkui' algavas kõrvallauses, samuti tingimuskõrvallauses (8a), muudel juhtudel võib seda asendada indikatiiv (8b) (vt nt Kugler 2000: 107; Hegedűs 2005: 259).

(8a) De jó lenne, ha szép lenne az idő. aga hea oleks, kui ilus oleks DEF-ART ilm.

'Küll oleks tore, kui ilm ilus oleks.'

(8b) Nem hiszem, hogy Péter ilyet ei uskuma:IND-DET.PREs.1sG, et Péter selline:ACC.SG mondott / mondott volna. ütles / ütlema:COND-INDET.IMPERF.3sG 'Ei usu, et Péter nii ütles/oleks öelnud.'

Kuna konditsionaali üks funktsioone on väljendada ebakindlust, on teatud juhtudel konditsionaali ja imperatiivivormi tähendus väga lähedane: mõlemad võivad viidata kõnehetkel teostumata ebakindlale sündmusele (9a). Teatud verbitüübis (- $l /-i k$-verbid) aga asendab konditsionaal imperatiivivormi (9b) (Hegedüs 2005: 52, 265-266). Konditsionaal 
võib ungari kõrvallauses väljendada ka soovi, enamasti täidab seda funktsiooni siiski imperatiiv (9c), ning rõhutada kõneleja distantseerumist öeldust (9d, eesti keeles on sama ülesanne kvotatiivil vrd Rä̈gitakse, et ta olevat just sellest innustust saanud) (Kugler 2000: 107). Võib seega eeldada, et ungari kõrvallauses esineb konditsionaali suhteliselt vähe, sama kinnitavad ka ungari grammatikad (nt Kugler 2000: 107).

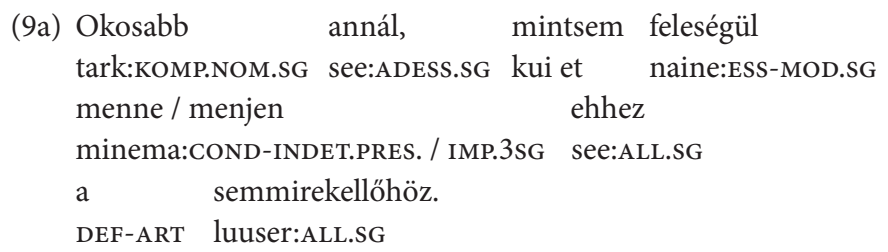

'Ta on liiga tark, et sellele luuserile mehele minna.'

(9b) Nem szeretném, ha

ei tahtma:COND-DET.PRES.1sG kui

lehámlana a böröm.

maha_tulema:COND -INDET.PREs.3sG DEF-ART mu nahk

'Ma ei taha, et mu nahk maha tuleb.'

(9c) Azt akarta, hogy meglátogassák

see:ACC.SG tahtis et PREF:külastama:IMP-DET.1sG

'Ta tahtis, et ma teda külastaks.'

(9d) Azt is mondják, hogy Kelemen

see:ACC.SG ka ütlema:PRES.IND-DET.3PL et Kelemen

innét nyerte volna a

siin:ABL.SG saama:COND-DET.IMPERF.3SG DEF-ART

kedvét.

innustus:ACC.SG

'Öeldakse sedagi, et Kelemen sai just sellest innustust/olevat just sellest innustust saanud.' 


\subsection{Konditsionaal eesti kõrvallauses}

Eesti konditsionaal on samuti alati modaalse tähendusega, tingivas kõneviisis predikaat viitab võimalikule olukorrale, protsessile või tegevusele ning irreaalsele tegevussituatsioonile. (EKG I 1995: 81) Lisaks tingimuslikkuse (10a) väljendamisele vormistab see muuhulgas ka kaudkõne (10b), võrdluskõrvallause (10c) ning otstarbelause (10d) predikaati ning võib öeldut modifitseerida (10e) (EKG II 1993: 34-35; Metslang 1999: 97-98, 116-118).

(10a) Ma läheks sinna, kui sa minuga kaasa tuleks.

(10b) Ema palus, et ma ostaks poest piima.

(10c) Kõrvalkorterist kostab kopsimist, justkui oleks seal kingsepatöökoda avatud.

(10d) Ta kiirustas, et jõuaks õigel ajal tööle.

(10e) Palun öelge, kas oleks võimalik juhatajaga kokku saada?

Sekundaarselt võib konditsionaal tingimuskõrvallausest või selle pealausest kujunenud ettepanekut väljendavas lauses (11a) või käskivas kõrvallauses (11b) edasi anda ka käsku (EKG II 1993: 35). Samuti võib kõrvallause predikaadi konditsionaalivorm olla tingitud pealause predikaadi (nt näima, paistma, tunduma; käskima, soovima, paluma, nõudma) semantikast. Mõnede autorite arvates võtab eesti konditsionaal seega kanda ka subjunktiivi (konjunktiivi) ülesandeid (Metslang 1999: 124; vt ka Pajusalu \& Pajusalu 2004: 263-264). Eesti kõrvallauses on konditsionaal niisiis tavaline (eriti et-kõrvallauses) ja sel on tavapärasest enam funktsioone.

(11a) Kuidas oleks, kui pistaksime rinnad kokku?

(11b) Mari nõudis, et Jüri ta rahule jätaks. 


\subsection{Imperatiivi ja konditsionaali funktsioonid ungari ning võrdlevalt eesti kõrvallauses}

Kõrvutades imperatiivi ja konditsionaali kasutust ungari ja eesti kõrvallauses köidab tähelepanu kaks põhierinevust:

1) käsku (soovi/palvet) väljendab ungari keeles enamasti imperatiiv, eesti keeles aga on võimalikke väljendusvahendeid rohkem: kõneviisisüsteemis on see funktsioon jussiivil, imperatiivi esineb kõrvallauses harva (3. pöörde vormide puhul pole võimalik imperatiivi ja jussiivi eristada), ent sama ülesannet täidab ka nt konditsionaal või $d a$-inifinitiivitarind (Metslang 2006: 113-114, 132);

2) ungari imperatiivi ja eesti konditsionaali ühisjooneks on nende sekundaarne funktsioon väljendada konjunktiivi (subjunktiivi) ülesandeid (vt tabel 1).

Imperatiivi-jussiivi puhul tuleneb erinevus peamiselt grammatikatraditsioonist (ungari kõneviisisüsteemis ei ole jussiivi, imperatiiv väljendab ka kaudset käsku; sama seisukoht oli omane ka vanematele eesti grammatikatele). Konjunktiivi funktsioonide kandumine vastavalt imperatiivi või konditsionaali kanda on aga märksa komplitseeritum. Artiklis uuritakse, kas ungari imperatiivi vormis ent konjunktiivi funktsioonis predikaadile vastab eesti keeles üldjuhul konditsionaal või on vastete skaala keerulisem. Kaudselt võimaldab ungari imperatiivi eesti tõlkevastete skaala teha mõningaid järeldusi ka selle kohta, milline ungari imperatiivi funktsioonidest on kõrvallauses enam levinud.

Kui imperatiivil on ungari keeles väga lai eesti keeles aga suhteliselt kitsas kasutusväli, hakkab konditsionaali puhul silma vastupidine tendents. Ungari keeles väljendab see põhiliselt tingimuslikkust, eesti keeles aga on konditsionaalil ka mitmeid sekundaarseid funktsioone, muuhulgas võib sel olla konjunktiivi tähendus (vt 2.4, 2.5). Kuna uurimistöös lähtutakse ungari keelest, on eelkõige võimalik kindlaks teha, kas ungari konditsionaalile vastab eesti keeles alati konditsionaal, nagu selle funktsioonide põhjal võiks oletada (vt tabel 2), või on selle vastete skaala siiski 
laiem. Kindlasti oleks huvitav edaspidistes uurimustes vaadelda ka eesti kõrvallause konditsionaali vasteid ungari keeles, ent uurimusmaterjali valikust tulenevalt see käesoleva artikli raamesse ei mahu.

TABEL 1. Ungari ja eesti kõneviiside põhilised funktsioonid kõrvallauses

\begin{tabular}{|c|c|c|c|c|}
\hline 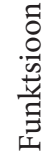 & $\begin{array}{c}\text { otsene käsk } \\
\text { (soov/palve) }\end{array}$ & $\begin{array}{l}\text { kaudne käsk } \\
\text { (soov/palve) }\end{array}$ & konjunktiiv & tingimuslikkus \\
\hline 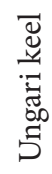 & imperatiiv & imperatiiv & imperatiiv & konditsionaal \\
\hline 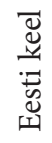 & imperatiiv & $\begin{array}{l}\text { imperatiiv } \\
\text { (jussiiv) }\end{array}$ & konditsionaal & konditsionaal \\
\hline
\end{tabular}

\section{Ungari kõrvallause imperatiivi- ja konditsionaalivormis predikaadi vasted eesti keeles}

Edasi võrreldakse ungari ja eesti imperatiivi ning konditsionaali funktsioone kõrvallauses. Uurimismaterjalina on kasutatud ungarikeelsetest tekstidest leitud imperatiivi- ja konditsionaalivormis predikaadiga kõrvallauseid ning nende eestikeelseid tõlkevasteid. Enamike tekstide puhul on ungari keel originaalkeel ja eesti keel sihtkeel: Imre Kertész "Sorstalanság"/“Saatusetus", esimesed 50 lk; Béla Hamvas "A bor filozófiája"/"Veinifilosoofia"; artiklid Horisondi 2006. aasta Ungari lisaväljaandest ja nende originaaltekstid ajakirjas Rubicon. Võrdlusmaterjali hulgas on ka George Orwelli romaani "1984” esimene peatükk, kus nii 
ungari- kui eestikeelne tekst on tõlked (korpus MULTITEXT-East ${ }^{1}$ ). Viimane mitmekesistab alusmaterjali ja võimaldab välistada ungari keele võimalikku mõju eestikeelsele tõlkele. Mõnes edaspidises uurimuses oleks kindlasti huvitav võrrelda ka erinevate allikate tulemusi.

Ungarikeelsest tekstist valiti välja (põim)laused ja otsiti üles nende vasted eestikeelsest tekstist. Kokku leiti 1928 tingimustele vastavat lauset. Artikli uurimismaterjalina on kasutatud ainult neid ungarikeelseid kõrvallauseid, mille predikaat on imperatiivis (123 lauset) või konditsionaalis (105 lauset) ning nende vasteid eestikeelses tekstis. 13 imperatiivis predikaadiga ja 3 konditsionaalis predikaadiga lause eestikeelne tõlge erines originaalist sedavõrd, et need uurimismaterjaliks ei sobinud. Seega vaadeldakse edaspidi 110 imperatiivis predikaadiga ja 101 konditsionaalis predikaadiga kõrvallauset. Indikatiivis predikaadiga kõrvallaused jäävad artikli huviorbiidist välja. Siinkohal väärib märkimist, et ehkki ungari grammatikates avaldatud seisukoha järgi peaks konditsionaali esinema ungari kõrvallauses suhteliselt harva ja märksa vähem kui imperatiivi (Kugler 2000: 107), näitab uurimismaterjal erinevaid tulemusi. Imperatiivis ja konditsionaalis predikaadiga kõrvallauseid oli materjali allikaks olnud tekstides peaaegu võrdselt (vastavalt 123 ja 105).

Ungari kõrvallause imperatiivivormis predikaadile vastab eesti keeles kõige sagedamini konditsionaal (40 lauset) või $d a$-infinitiivis predikaadiga kõrvallause (30). Küllalt sageli vastab ungarikeelse kõrvallause imperatiivivormis predikaadile eesti keeles lihtlausesse sisestatud $d a$-infinitiiv predikaadi osana, mõnikord ka muus funktsioonis (21), harva esineb samas positsioonis ma-infinitiivi (5). Eesti keeles vastab imperatiiv (jussiiv) ungari kõrvallause imperatiivile harva (10), kuna kõik võimalikud jussiivi juhud olid 3. pöördes (7), polnud võimalik imperatiivi ja jussiivi teineteisest vormiliselt eristada ning lihtsuse huvides käsitletakse neid edaspidi koos imperatiivivormidega (vt tabel 2).

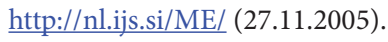


TABEL 2. Ungari imperatiivi- ja konditsionaalivormis predikaadiga kõrvallausete vasted eesti keeles

\begin{tabular}{|c|c|c|c|c|c|c|c|c|c|c|}
\hline \multirow{2}{*}{$\begin{array}{l}\overline{\widetilde{J}} \\
\mathbb{0} \\
\bar{s}\end{array}$} & \multicolumn{5}{|c|}{ Imperatiiv } & \multicolumn{5}{|c|}{ Konditsionaal } \\
\hline & \multicolumn{5}{|c|}{110} & \multicolumn{5}{|c|}{101} \\
\hline $\begin{array}{l}\overrightarrow{\tilde{D}} \\
\text { | }\end{array}$ & 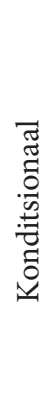 & 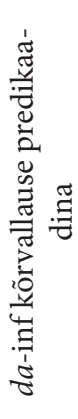 & 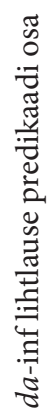 & 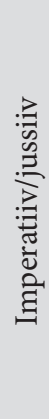 & 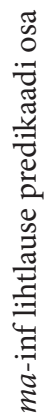 & 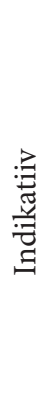 & 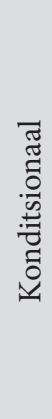 & 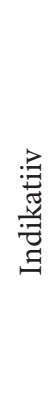 & 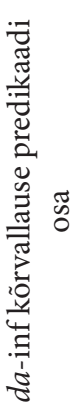 & 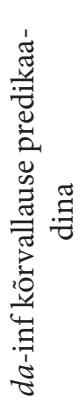 \\
\hline & 40 & 30 & 21 & 10 & 5 & 4 & 81 & 13 & 4 & 3 \\
\hline
\end{tabular}

\subsection{Ungari kõrvallause imperatiivivormis predikaadi vasted eesti keeles}

Ungari imperatiivile vastab konditsionaalivormis või $d a$-infinitiivis predikaadiga kõrvallause enamasti otstarbelauses, st kõrvallause predikaadi vorm tuleneb siin pea- ja kõrvallause semantilisest suhtest, nt

(12) Vagy azért, hogy "maga mellett lásson ezen az utolsó napon, mielőtt elszakad hazulról": mert ezt is mondta, bár igaz, máskor. (K1)

Või sellepärast, et ta "näeks mind enda kõrval viimasel päeval enne kodust lahkumist"; sest ta ütles ka seda, kuigi, tõsi küll, teine kord. (K1) 
(13) Lehajolt, ráejtette szinte a száját mostohaanyám kezére, hogy elvégezze rajta a szokásos kézcsókját. (K3)

Ta kummardas ja surus suu peaaegu vastu võõrasema kätt, et sooritada oma harjumuspärane käesuudlus. (K2)

(14) A nők, hogy lényük spiritualitását intenzívebbé tegyék, illatszereket használnak, a férfiak pedig dohányoznak. (H5)

Naised kasutavad lõhnaõlisid, et teha oma olemuse spirituaalsust intensiivsemaks, mehed seevastu suitsetavad. (H4)

Kuna eesti keeles on otstarbelause predikaatverb tingivas kõneviisis või da-infinitiivis (viimane saab olla predikaadiks vaid juhul, kui pea- ja kõrvallause tegevussubjektid on identsed), on selline tulemus ka ootuspärane.

Harvem vastab ungari imperatiivivormile eesti keeles konditsionaalis või $d a$-infinitiivis predikaadiga kõrvallause sihitis-, alus-, põhjusmäärus- või täiendkõrvallauses.

Küllalt sageli vastab ungari kõrvallause imperatiivivormis predikaadile eesti keeles $d a$-infinitiiv (harva ka ma-infinitiiv), mis on predikaadi osa (finiitvormis verb on sel juhul indikatiivis) või laiendab mõnda lauseliiget, st põimlausest on tõlkes saanud lihtlause, nt

(15) --- s fölkérte Sütő urat, legyen mostohaanyám segítségére ebben a dologban az ő üzleti tapasztalataival és szakértelmével. (K2)

--- ja ta palus härra Sütől olla oma ärikogemuste ja asjatundlikkusega minu võõrasemale selles asjas abiks. (K2)

(16) < Ohu.1.2.25.13> Winston sohasem próbálta meg, hogy ezt a sejtelmét ellenőrizze: igaz, nem is volt rá módja, hogy efféle kísérletet tegyen. $<$ Oet.1.2.25.13> Winston ei olnud küll iial teinud vähimatki katset seda oletust kontrollida; ja muidugi polnud tal selleks võimalustki.

(17) Akkor apám sürgette, lássanak már neki a rájuk váró munkának, --(K3)

Siis ärgitas isa selle tööga juba peale hakkama, --- (K3)

Ungari kõrvallause imperatiivse predikaadi eestikeelse vastena tuleb ette ka indikatiivis predikaati. Ühel juhul andis siin imperatiivivormis sisal- 
duvat modaalsust edasi modaalverb (põhiverb on ma-infinitiivis), ent enamasti jääb see kajastamata, nt

(18) --- de azt ők is egyformán helyeselték, hogy dolgozni menjek, --(K12)

--- aga selle olid nad üksmeelselt heaks kiitnud, et ma tööle läksin, --- (K15)

(19) Azt se tudtam, merre is forduljak hamarjában, --- (K21)

Ma ei teadnud isegi seda, kuhu ma pean kõigepealt pöörduma, --(K28)

Imperatiivi/jussiivi, mis oleks ungari nn pärisimperatiivi vahendajana eelduspärane (vt 2.1), esineb eesti kõrvallauses ungari imperatiivi vastena väga harva (10).

Selgeid imperatiivi juhte oli vaid 3 (laused, kus predikaat oli 2. pöördes), mis on eesti imperatiivi funktsioonidest lähtuvalt ootuspärane. Tegemist oli pigem otsekõnele lähedaste lausetega, nt

(20) Megint csak azt mondom, hogy: bort igyatok! (H34)

Ma ütlen veel kord seda: jooge veini! (H28)

Veidi enam esines vorme, mille puhul imperatiivi ja jussiivi eristamine võimalik polnud (predikaat 3. pöördes), nt

(21) Még azt is hozzátette, igyekezzem, mert szükség lehet rám. (K1) Ta oli veel lisanud, et püïdku ma kohal olla, sest mind võib vaja minna. (K1)

(22) Mondtam a lánynak, próbálja magáról is elképzelni a dolgot. (K14) Ütlesin tüdrukule, et proovigu seda kujutleda enda peal. (K18)

Ungari imperatiivi funktsioonirohkus kajastub ilmekalt selle eesti vastete mitmekesisuses: imperatiiv/jussiiv on nende seas haruldane, suurema osa tõlkevastetest moodustasid konditsionaalivorm ja da-infinitiivikonstrukstioonid (vt tabel 2). See toetab kaudselt mõnede tänapäeva ungari keele uurijate seisukohta, et käsu(soovi/palve) väljendamine on ungari keeles vaid üks imperatiivi funktsioone, imperatiivivormi 
kasutus tuleneb pigem teatud semantilisest ebakindluselemendist pealauses (vt 2.1). Eesti kõrvallauses tingib sarnane element konditsionaali või $d a$-infinitiivikonstruktsioonide kasutamise. Kuna seni pole välja töötatud sajaprotsendilisi kriteeriume, mille põhjal ungari kõrvallause pärisimperatiivi alati konjunktiivist eristada, on raske kindlaid järeldusi teha, ent eesti tõlkevasted viitavad sellele, et pärisimperatiiv on ungari kõrvallauses haruldane (vt tabel 2), pigem täidab imperatiivivorm konjunktiivi ülesandeid. Seega on uurimuse tulemused vastuolus Nóra Kugleri seisukohaga, mille järgi ungari imperatiivi põhiülesanne kõrvallauses on väljendada vahendatud käsku (Kugler 2000: 107). Kindlate järelduste tegemiseks oleks siiski vajalik ungarikeelse materjali põhjalikum analüüs. Eesti tõlkevastete mitmekesisust põhjustab ka asjaolu, et vahendatud käsku võib eesti keeles väljendada nii kõrvallause konditsionaal kui ka da-infinitiivitarind (vt 6a, 6b).

\subsection{Ungari kõrvallause konditsionaalivormis predikaadi vasted eesti keeles}

Ungari konditsionaalile vastab eesti tekstis enamasti konditsionaal (vt tabel 2).

(23) Szerettem volna, ha apám már nem lenne itt. (K5)

Oleksin tahtnud, et isa ei oleks enam siin. (K7)

(24) Az 1956-os magyar forradalommal kapcsolatban máig élő legalapvetőbb mítosz éppen az, amely szerint a felkelés tulajdonképpen győzhetett volna, --- (Rubicon 10/2001)

1956. aastaga seotud tänaseni elavatest müütidest on kõige põhilisem see, mille kohaselt oleks ülestõus võinud võita, --- (Horisont)

Küllalt sageli on ungari kõrvallause konditsionaali modaalne tähendus eesti keeles kadunud: eesti keeles vastab ungari konditsionaalivormile indikatiivis või $d a$-infinitiivis predikaat, nt

(25) Az egyik legáltalánosabban elterjedt korabeli illúzió az volt, hogy a forradalom eredményeként a Szovjetunió hajlandó lenne beleegy- 
ezni magyarorszagi függetlenségének helyreállításába, amennyiben az a semlegesség formájában következne be. ( Rubicon 10/2001)

Omal ajal oli kõige enam levinud illusioon, et revolutsiooni tulemusel on NL nõus taastama neutraliteedile rajatud Ungari iseseisvuse. (Horisont)

(26) Nem tudtam, mit mondhatnék erre, s nem is mondtam semmit. (K1) Ma ei teadnud, mida selle peale kosta, ega öelnud midagi. (K1)

Kui ungari konditsionaalivormile lisandub võimalikkust väljendav liide -hat/-het, annab viimase tähendust eesti keeles enamasti edasi finiitne modaalverb, põhitähendust kandev verb aga on $d a$-infinitiivis, seega jääb konditsionaali modaalsus ka siin väljendamata.

(27) Gondoltam, most így akkor közelebbről is megismerhetném: --(K5)

Mõtlesin, et nüüd saan teda sedasi ka lähemalt tundma õppida: --(K6)

Ungari konditsionaalil on eesti keeles suhteliselt vähe vastevariante. See on ka eelduspärane: nii ungari kui ka eesti keeles annab konditsionaal edasi peamiselt tingimuslikkust. Seega vastab ungari konditsionaalile ülekaalukalt konditsionaal ka eesti keeles. Indikatiivis või $d a$-infinitiivis predikaati on kasutatud lausetes, kus tingimuslikkuse väljendamist pole eesti keeles oluliseks peetud.

\section{Kokkuvõtteks}

Vaadeldes ungari kõrvallause imperatiivi ja konditsionaali vastete skaalat eesti keeles (vt tabel 2) näeme, et imperatiiv on ungari keeles komplitseeritud kõneviis, mille funktsioonide väljendamiseks eesti keeles on väga mitmekesised võimalused; konditsionaalile aga vastab eesti keeles ülekaalukalt konditsionaal.

Ungari imperatiivivormi vastena on eesti keeles imperatiiv/jussiiv haruldane, sagedamini on selle vasteks konditsionaal või $d a-$ infinitiiv(ikonstruktsioon), kusjuures viimased vastavad ungari 
imperatiivile enamasti otstarbelauses, harvem muudes lausetüüpides. Kuna aga ungari keeleteadlased ei paku seni selgeid kriteeriume, mille põhjal pärisimperatiivi ja konjunktiivi funktsioonis imperatiivi eristada, ei saa lõplikke järeldusi teha. Samuti tuleb arvesse võtta, et eesti keeles on kaudse käsu väljendamiseks imperatiivist/jussiivist enam levinud vahendeid (konditsionaal kõrvallauses ja da-infinitiivitarind). Tõlkevastete mitmekesisus, samuti konditsionaali ja $d a$-infinitiivis predikaadiga kõrvallausete ning $d a$-lauselühendiga tõlkevastete rohkus viitab siiski sellele, et ungari imperatiivivorm täidab kõrvallauses peamiselt konjunktiivi ülesandeid, st kõrvallause verbi vorm tuleneb mingi pealause leksikaalse elemendi (enamasti predikaadi) semantikast; käsu väljendamine on pigem ungari kõrvallause imperatiivi sekundaarne funktsioon. Kindlate järelduste tegemiseks oleks vajalik ungarikeelse materjali põhjalikum analüüs.

Konditsionaali funktsioonid aga on ungari keeles küllaltki kitsad, piirdudes peamiselt tingimuslikkuse väljendamisega (ning on ka sel puhul sageli fakultatiivne). Seda kinnitavad ungari kõrvallause konditsionaalis predikaatide eesti vasted. Ülekaalukalt vastab ungari konditsionaalile konditsionaal ka eesti keeles. Mõnikord on konditsionaalivormis sisalduv modaalsus eesti keeles edastamata. Konditsionaal on ungari kõrvallauses palju enam levinud, kui teoreetiliste allikate põhjal võiks arvata: konditsionaalis predikaadiga kõrvallauseid on vaadeldud materjali hulgas peaaegu sama palju kui imperatiivseid (vt ptk 3).

\section{Lühendid}

$\begin{array}{ll}\text { ABL } & \text { ablatiiv } \\ \text { ACC } & \text { akusatiiv } \\ \text { ADESS } & \text { adessiiv } \\ \text { ALL } & \text { allatiiv } \\ \text { ART } & \text { artikkel } \\ \text { COND } & \text { konditsionaal } \\ \text { DAT } & \text { daativ } \\ \text { DEF } & \text { definiitne }\end{array}$




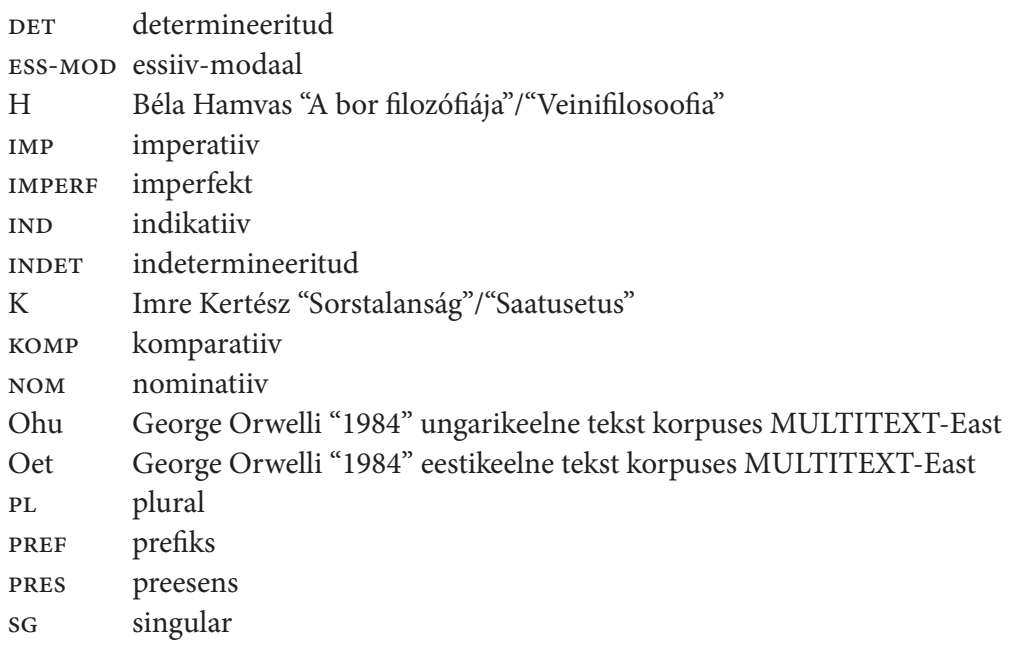

\section{Kirjandus}

Aradi, András 2004. A magyar kötőmódhasználat kérdéséhez, Előadás a VII. Nemzetközi Magyar Nyelvtudományi Kongresszuson. http://www.nytud. hu/NMNyK/eloadas/aradia.rtf (22.04.2010).

Erelt, Mati, Helle Metslang 2004. Grammar and pragmatics: Changes in the paradigm of the Estonian imperative. - Linguistica Uralica XL (3), 161-178.

É. Kiss, Katalin 1999. Mondattan. - Katalin É. Kiss, Ferenc Kiefer, Péter Siptár (Szerk.). Új magyar nyelvtan. Budapest: Osiris Kiadó, 15-184.

EKK 1997= Erelt, Mati, Tiiu Erelt, Kristiina Ross 1997. Eesti keele käsiraamat. Tallinn: Eesti Keele Sihtasutus.

EKK 2007= Erelt, Mati, Tiiu Erelt, Kristiina Ross 2007. Eesti keele käsiraamat. Tallinn: Eesti Keele Sihtasutus.

EKG I = Erelt, Mati, Reet Kasik, Helle Metslang, Henno Rajandi, Kristiina Ross 1995. Eesti keele grammatika I. Morfoloogia. Sõnamoodustus. Tallinn: Eesti TA KKI.

EKG II = Erelt, Mati, Reet Kasik, Helle Metslang, Henno Rajandi, Kristiina Ross 1993. Eesti keele grammatika II. Süntaks. Tallinn: Eesti TA KKI.

Givón, Talmy 2001. Syntax I. Amsterdam: Benjamins. 
Groot, Casper de 2010. Mood in Hungarian. - Björn Rothstein, Rolf Thieroff (Eds.). Mood in the Languages of Europe. Studies in Language Companion Series 120. Amsterdam: Benjamins, 551-568.

Hegedűs, Rita 2005. Magyar nyelvtan. Formák, funkciók, összefüggések. Budapest: Tinta Könyvkiadó.

Hegedűs, Rita 1990. A konjunktivusz problémája a németben és a magyarban. Orsolya Egyed, Béla Ciay, Orsolya B. Nádor (Szerk.). Hagyományok és módszerek. Az I. Nemzetközi Hungarológia-Okatatási Konferencia elöadásai II. Budapest: Nemzetközi Hungarológiai Központ, 63-74.

Keresztes, László 1997. Praktiline ungari keele grammatika. Hungarolingua. Debrecen: Debreceni Nyári Egyetem.

Kugler, Nóra 2000. Az igeragozás. - Borbála Keszler (Szerk.). Magyar grammatika. Budapest: Nemzeti Tankönyvkiadó, 104-122.

Marques, Rui 2009. On the selection of mood in complement clauses. - Lotte Hogeweg, Helen de Hoop, Andrej Malchukov (Eds.). Cross-Linguistic Semantics of Tense, Aspect and Modality. Linguistcs Today 148. Amsterdam: John Benjamins, 179-204.

Metslang, Helle 2006. Imperatiivist ja direktiivsusest ning nende dünaamikast eesti ja soome keeles. - Helle Metslang, Siiri Soidro (Toim.). Lähivertailuja 16. Tallinna Ülikooli eesti filoloogia osakonna toimetised 7. Tallinn: TLÜ kirjastus, 111-134.

Metslang, Helle 2004. Imperative and related matters in everyday Estonian. - Linguistica Uralica XL (4), 243-256.

Metslang, Helle 1999. Is the Estonian and Finnish conditional actually a conditional? - Mati Erelt (Ed.). Estonian Typological Studies III. Tartu Ülikooli eesti keele õppetooli toimetised 11. Tartu: Tartu University, 97-128.

MG = Balogh, Judit, Lea Haader, Borbála Keszler, Nóra Kugler, Krisztina Laczkó, Klára Lengyel 2000. Magyar grammatika. Budapest: Nemzeti Tankönyvkiadó.

MLN = Bárneti, Zoltán, Kálmán Dudás, Beáta Gyuris, László Kálmán, Attila Novák, Viktor Trón 2001. Magyar leíró nyelvtan. Mondattan I. - Segédkönyvek a nyelvészet tanulmányozásához VI. Budapest: Tinta Könyvkiadó.

MMNyR = Deme, László, Vilmos Farkas, Antónia S. Hámori, Imre Samu, Sándor B. Károly, Éva Lőrinczy, Ilona H. Molnár, Éva Ruzsiczky, György Szépe, Mihály Temesi, József Tompa 1962. A mai magyar nyelv rendszere. II. Budapest: Akadémiai Kiadó.

Molnár, Ilona 1994. Az alárendelt mondatbeli felszólító módról: a magyar kötőmód kérdéséhez. - Marianne Bakró-Nagy (Szerk.). Nyelvtudományi közle- 
mények 94. Budapest: Magyar Tudományos Akadémia Nyelvtudományi Intézete, 5-43.

Pajusalu, Renate, Karl Pajusalu 2004. The conditional in everyday Estonian: It's forms and functions. - Linguistica Uralica XL (4), 257-269.

Palmer, Frank Robert 2001. Mood and Modality. Cambridge: Cambridge University Press.

Pataki, Pál 1984. A francia subjonctif és a magyar kötőmód. - Általános Nyelvészeti Tanulmányok XV. Budapest: Akadémiai Kiadó, 207-218.

Pomozi, Péter 1991. Néhány gondolat a magyar konjuktívuszról. - Zoltán Éder (Szerk.). Dolgozatok a magyar mint idegen nyelv és a hungarológia köréből 26. Budapest.

Prileszky, Csilla 1974. A felszólító módú mellékmondat néhány kérdéséről. - Imre Samu, István Szathmári, László Szüt (Szerk.). Jelentéstan és stilisztika. A magyar nyelvészek II. Nemzetközi kongresszusának elöadásai. NytudÉrt 83. Budapest: Akadémiai Kiadó, 473-475.

Pusztay, János 1998. A magyar imperatívuszi állítmányú mellékmondatok (IÁM) megfelelései az észtben. - Folia Estonica VI. Észt-magyar összevetés II. Szombathely: Berzsenyi Daniel Tanarkepzö Föiskola, 19-34.

Rüütmaa, Tiina 2007. Kõneviisid ungari ja eesti kõrvallauses. - János Pusztay (Toim.). Folia Estonica XII. Szombathely: Berzsenyi Daniel Tanarkepzö Föiskola, 88-100.

Tompa, József 1972. Kleine Ungarische Grammatik. Budapest: Akadémiai Kiadó. Tóth, Enikő 2005. Az alárendelt mellékmondatbeli kötő- illetve felszólító módról. - Balázs Sinkovics (Szerk.). Nyelvész-doktorandusok dolgozatai. LingDok 4. Szegedi Tudományegyetem Nyelvtudományi Doktori Iskola.

\section{Tiina Rüütmaa}

Tallinna Ülikool, eesti keele ja kultuuri instituut

Narva mnt 29

10120 Tallinn, Estonia

rtiina@tlu.ee 


\title{
Imperative and conditional in Hungarian and Estonian subordinate clause
}

\author{
TIINA RÜÜTMAA \\ Tallinn University
}

The article compares the functions of the Hungarian and Estonian imperative and conditional in the subordinate clause in order to map the mutual relations of the two moods. After a survey of the treatment of the imperative (jussive) and conditional moods in modern Hungarian and Estonian grammars a number of subordinate clauses with either an imperative or conditional predicate, found from Hungarian texts, are compared with their Estonian equivalents.

Hungarian grammars traditionally speak of three moods: indicative, conditional and imperative, but there has been a lot of discussion over a possible conjunctive sharing its morphological marker with the imperative. At first the conjunctive use of an imperative form was considered specific to the Hungarian imperative, but more recent sources treat the conjunctive imperative as a separate linguistic category.

The earlier Estonian grammatical tradition used to distinguish between four moods: indicative, conditional, imperative and quotative. Modern grammars add jussive expressing an indirect command.

The Estonian equivalents of Hungarian imperative and conditional subordinate clauses reveal that the Hungarian imperative is a complicated category with many functions, for which Estonian has a lot of different ways of expression, whereas most of the Estonian translations of the Hungarian conditional use a conditional form.

The most frequent Estonian equivalent of the Hungarian imperative form is either a conditional or a construction with the $d a$-infinitive, while an imperative/jussive is rather rare. This proves that one of the main functions of the Hungarian imperative is to act as the conjunctive: the imperative form of the subordinate verb depends on the semantics of a lexical element of the main clause, while the expression of a command is rather a secondary function. However, definitive conclusions cannot be made for lack of definitive criteria 
to differentiate between the Hungarian imperative proper and conjunctive imperative. Moreover, in Estonian there are more widespread means to express an indirect command than the imperative/jussive, such as, e.g., a conditional subordinate clause and a construction with the $d a$-infinitive).

The functions of the Hungarian conditional are actually rather limited being mainly confined to expressing conditionality (often even that is optional). This is also proved by the Estonian equivalents of Hungarian subordinate predicates in the conditional form: in most cases the Hungarian conditional is translated into Estonian by the same mood. However, in Hungarian subordinate clauses the conditional is more frequent than could be guessed from theoretical sources as the analysed subordinate clauses contained almost as many conditional predicates as imperative ones.

Keywords: complement clause; final clause; conjunctive; subjunctive; jussive; Estonian; Hungarian 